\title{
Private Military Companies in the Russian Federation Foreign and Security Policies in 2014-2019
}

\author{
Aivaras GIEDRAITIS ${ }^{1}$ \\ ${ }^{1}$ General Jonas Žemaitis Military Academy of Lithuania, Department of Political Science, Šilo str. 5A, 10322 Vilnius, \\ Lithuania
}

E-mails: ${ }^{1}$ aivaras.miksa.giedraitis@gmail.com

\begin{abstract}
The aim of the scientific article is to reveal motives and features of using private military companies in Russian Federation foreign and security policy in 2014-2019. In order to do so, qualitative research method is applied, using case analysis method. From the analysis of the motives for the use of private military companies and conventional forces, it can be said that they are similar, as the use of both military structures allows to achieve more or less the same interests. However, it was observed that in terms of the specifics of the forces and the diversity scheme of social deviations, private military and security companies are more similar to regular forces. Nevertheless, both types of private companies help Russia avoid direct liability for various violations of the law. Considering the case of Russia analyzed in the study, the factors explained in the microtheory are adjusted, supplemented and interrelated. The analysis found that not all regions that are far from Russia are financially beneficial, but strategically, all give Russia an advantage over the United States.

This work is beneficial for researchers doing study cases on Russian Federation foreign and security policy. Due to the novelty and relevance of the research object, a new microtheory in political science has been applied. Research is carried out using principal-agent theory which was only used analyzing US case.
\end{abstract}

KEY WORDS: private military and security company, private military company, mercenary, foreign policy, security policy, Russia, conflict

\section{Introduction}

As the nature of war changes [1], the military tools and strategies of states change too [2]. Increasingly, private military and security companies (PMSCs) or private military companies (PMCs) are being deployed to pursue states interests rather than regular forces. Nowadays, Russian PMCs are being hired to operate in regions such as Syria, Africa, Ukraine and Venezuela [3] and to pursue Kremlin objectives [4]. The importance of PMCs have increased since Russia's invasion in Ukraine and annexation of Crimea in March 2014 [5]. Reliance on PMCs is not the main strategy of Russian policy, but it covers a substantial part of it. Revealing the motives and features of involvement of mercenaries would provide the basis for research which would allow to define how Russia employs PMCs, what its goals are and what results it has achieved.

The analysis is conducted applying principal-agent theory, would begin to explain state choices and behaviours of Russia and PMCs in its strategy. According to the principal-agent theory, delegation is a cost-saving tool useful for the principal who lacks the knowledge and expertise associated with the task [6]. The microtheory explains the circumstances of delegation and the interests of the state that determine the use of PMCs. The case of Russian Federation is analysed based on these factors.

The object of the study - use of private military companies in Russian Federation foreign and security policies 2014-2019, in the regions of Syria, northeast and central Africa, Ukraine and Venezuela.

The aim of this study is to disclose goals and traits of using private military companies in Russian Federation foreign and security policies in 2014-2019.

Defensive statement - the use of private military companies in the Russian Federation's foreign and security policy is close to that of conventional forces, avoiding responsibility for its actions.

Method of investigation. To reveal motives, goals and traits of using PMCs in Russian Federation's foreign and security policy in 2014-2019, qualitative research method is applied. The case study approach seeks to assess Russia's assumptions on reliance on PMCs, the cases selected for the study are limited by period (2014-2019) and within the regions of Syria, northeast and central Africa, Ukraine and Venezuela.

\footnotetext{
${ }^{1}$ Corresponding author.

E-mail address: aivaras.miksa.giedraitis@gmail.com
} 


\section{Literature Review}

Various literature was analyzed during the study:

- $\quad$ Reports from monitoring organizations (Organization for Security and Cooperation in Europe) and US intelligence are reliable, accurate, objective and comprehensive, but cover only a narrow area that helped collect data on the activities of PMCs in different regions;

- Posts on social media (mercenary speeches) are comprehensive and objective, but not authoritative and accurate, as every post can be fake or false. Such records help in explaining the characteristics of the use of PMCs;

- Academic books, monographs, and articles are authoritative, comprehensive, but can be seen from different perspectives. Martin van Creveld in "More on War", Mary Kaldor in "New and Old Wars: Organized Violence in a Global Era" and Geraint Hughes in "My Enemy's Enemy: Proxy Warfare in International Politics" explain how the concept of war has changed and what new actors became involved in the "New" and delegated wars. To find out who the private sector actors are, Hannah Tonkin "State Control Over Private Military and Security Companies in Armed Conflict", Christopher Kinsey "Corporate Soldiers and International Security: The Rise of Private Military", David Shearer "Private Armies and Military Intervention", PW Singer "Corporate Warriors: The Rise of the Privatized Military Industry. The Updated Edition" books identify types of mercenaries, distinguish between PMSCs, PMCs, and PSCs, and describe the concepts and functions of those companies. In order to purposefully assess the motives and features of the use of Russian PMCs, principal-agent theory will be discussed with the help of Scott Sigmund Gartner "The Multiple Effects of Casualties on Public Support for War: An Experimental Approach", Darren G. Hawkins, David A. Lake, Daniel L. Nielson and Michael J. Tierney "Delegation and Agency in International Organizations", Margaret E. Keck and Kathryn Sikkink "Activists Beyond Borders: Advocacy Networks in International Politics", Idean Salehyan "The Delegation of War to Rebel Organizations", Laura H. Wimberley "Pyrrhic Peace: Governance Costs and the Utility of War" books and articles;

- The material of analytical centers is reliable, complete and accurate, but not always objective. Analytical articles help to elucidate the motives for the use of PMCs;

- Official documents (contracts, doctrines, strategies, etc.) are objective, accurate and reliable, but not complete. The study uses The Montreux Document, Protocol I of the Geneva Convention, the Maritime Doctrine of the Russian Federation until 2020, the Military Doctrine of the Russian Federation until 2020, the National Security Strategy of the Russian Federation until 2020, and the Foreign Policy Concept of the Russian Federation until 2020. The documents help to clarify the difference between a mercenary and a PMSC and Russia's operational goals in different regions and seas;

- Online sources have detailed and objective information, but are not reliable.

\section{Private Military and Security Companies: their use, Distribution and Principal-Agent Theory}

Rapid change in the field of war and the changing nature of war accelerate the development of armies, the application and improvement of military innovations, and the implementation of military action at various levels. Mary Kaldor wrote that the outbreak of the "New Wars," characterized by ties between states and non-state actors and violence against civilians replaced the "Old Wars" [2]. Emerging new threats - terrorism, uprisings and so on challenges the implementation of new solutions. Russia is not directly involved in the conflict but is using the PMCs and pursuing personal interests by entrusting them with tasks.

The nature of war, along with its space and actors, is changing. The ongoing conflicts are described as delegated wars, characterized by long-term relations between external actors and the militants, i. e. mercenaries. Ongoing funding, military training, weapons and other material assistance reach them through external actors [7]. Hired private companies, also known as the PMSCs or PMCs, have become particularly active in this type of war in Syria, Northeastern and Central Africa, Ukraine, the Donbass conflict, and Venezuela.

Although PMSCs is the most well-known actor, it is not the only one in the private sector. The actors in private military and security activities - mercenaries, PMSCs, volunteers, soldiers in foreign forces and national soldiers - are similar but differ in their social stigma (deviation).

According to Hannah Tonkin, at the end of the scheme (see Fig 1) mercenaries predominate as they have the strongest social deviation from their activities. According to Article 47 of Protocol I to the Geneva Conventions [8], mercenaries relationship with the hiring state is short-term, without signing or following a reciprocal agreement [9]. In contrast to mercenaries, PMSCs has its own legitimacy and diversity of clients [10]. They are registered corporations associated with their state in a variety of formal and informal ways. The key factor that determines the 
higher position of PKSK than the mercenary in the diversity scheme of social deviations. Volunteers in the social deviation diversity scheme are above mercenaries and PMSC. According to the 1997 UN report on mercenaries, any altruistic voluntary involvement in conflict actions is not considered a crime because the activities are not based on self-interest [11]. Soldiers who have been integrated into foreign forces take a slightly different and higher position. One such example is the French Foreign Legion. According to James Larry Taulbee, French people join the legion for a sense of duty and loyalty, while foreigners only join for money or a desire to take part in military action [12]. Soldiers of the state's conventional forces fighting for their homeland occupy the highest place in the diversity scheme of social deviations. They are the most legitimate military figures in international relations, motivated by nothing but a sense of patriotism [13].

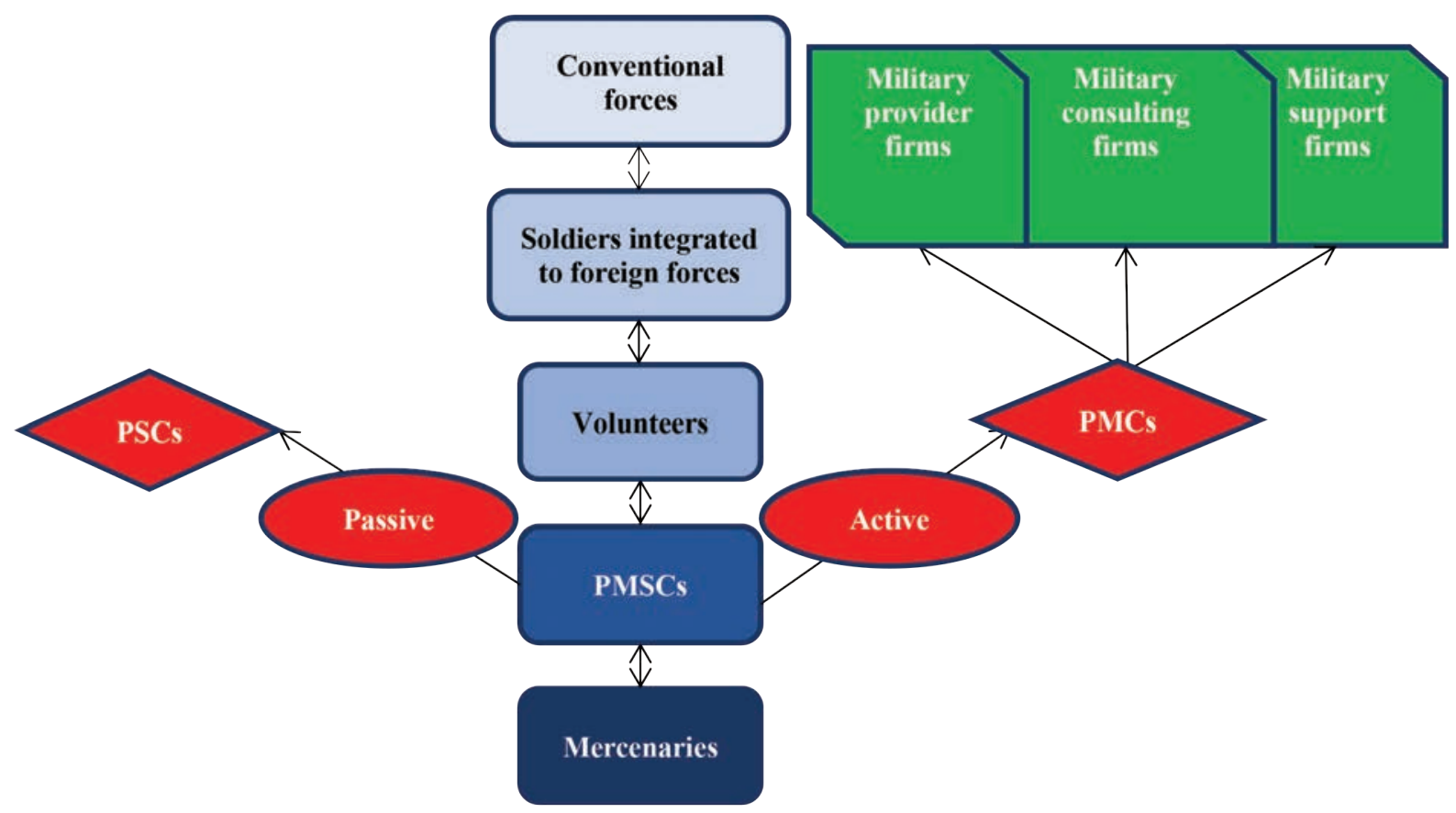

Fig 1. Scheme of diversity in social deviations and distribution of PMSCs. Source: compiled by author

The change in the concept of warfare gives rise to innovative non-traditional methods of warfare and new actors in delegated warfare who, together with the states, form a link that allows the latter to delegate tasks to mercenaries. Although there are different types of mercenaries due to their social deviations (see Fig 1), states are increasingly confronted with the PMSCs, especially the PMCs. The PMSCs operates worldwide, but in practical terms, narrower types of companies may differ fundamentally: the PSCs, which is knowledgeable in policing, is relevant to Western practice, and the PMCs, which is adept at combat missions, is relevant to Russian practice. The concept of the PMCs emphasizes the field of activity of militant mercenaries, so it is most appropriate to use the term PMCs when studying the activities of Russian privately hired companies, the motives and features of their use.

\section{Theoretical Interpretation of the Use of Private Military Companies}

Although realism focuses on the interpretation of state policy objectives [14], it is not appropriate for explaining why Russia uses state actors indirectly rather than its own regular forces. As the PMC is only an instrument, the theory of realism is too high, so it is most appropriate to refer to the principal-agent theory in the study of the use of the PMC in Russia's foreign and security policy, their motives and features. 

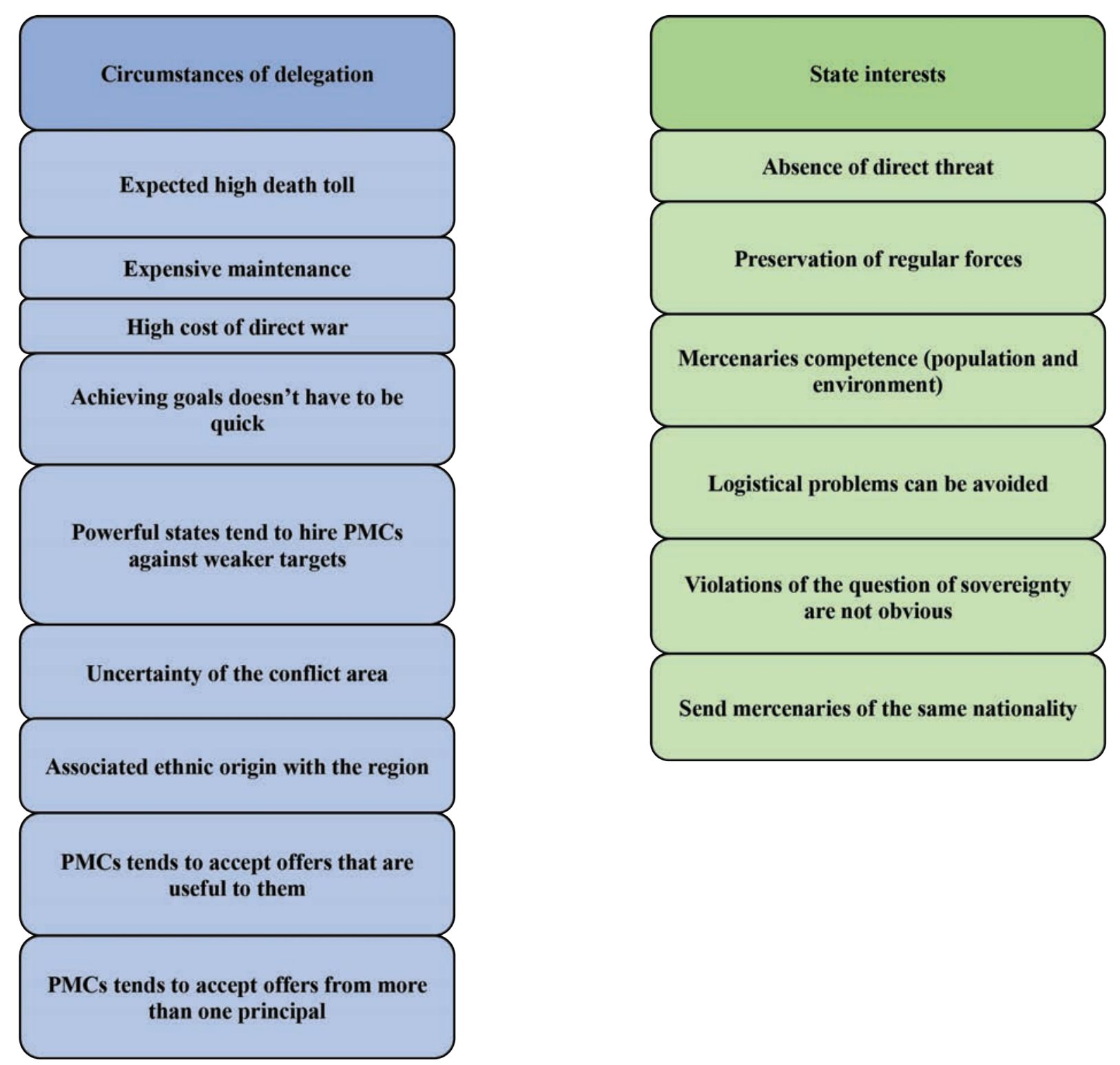

Fig 2. Factors determing the delegation of work and the interests of the state in hiring PMCs. Source: compiled by author

Microtheory explains the dilemmas that arise and the benefits they provide, both from the perspective of the principal and from the perspective of the agent. According to the theory, the analysis can reveal the motives and features of the use of the Russian PMC - why delegation is a useful strategy and how such practices are implemented. The theoretical circumstances of the delegation of activities and the interests of the state form the basis for the analysis of the case of Russia (see Fig 2). Although microtheory is applied in economics, scholar I. Salehyan explains in detail how the principal-agent theory can be applied in the political sciences [15]. The reasons given by the Salehyan study as to why this is the most useful tool in the US and why delegation is most likely, the principal-agent theory is appropriate in interpreting the Russian case and at the level of such analysis.

\section{Foreign and Security Policy Objectives of the Russian Federation in the Regions Using Private Military Companies}

It is no secret that Russia hires PMSCs and the PMCs to pursue its interests. The RF writes in its military doctrine that "one of the features of modern warfare is the use of the PMCs in military conflicts" [16]. The Kremlin has important motives for deploying privately hired groups of militants in Syria, northeastern and central Africa, Ukraine and Venezuela. One PMC is not enough for Russia to achieve its goals in all the above-mentioned regions, so it uses several different companies that differ not only in their type but also in their functions. In the course of the analysis of the study, a table was created (see Table 1), in which all the world-famous main Russian PMCs and PMSCs are discussed in a structured way. However, it is not all the companies that Russia hires. As far as is known, 
the Kremlin's delegated work is carried out by eleven PMCs, but not all data are available due to a lack of information and unavailability of existing information.

Table 1.

Russian PMSCs and PMCs.

\begin{tabular}{|c|c|c|c|c|c|}
\hline $\begin{array}{l}\text { Private } \\
\text { military and } \\
\text { security } \\
\text { company }\end{array}$ & $\begin{array}{l}\text { Type of } \\
\text { company }\end{array}$ & $\begin{array}{l}\text { Commander/ } \\
\text { Manager }\end{array}$ & $\begin{array}{l}\text { Regions in which } \\
\text { it operates }\end{array}$ & Activities & Other \\
\hline $\begin{array}{l}\text { „Wagner } \\
\text { Group““ }\end{array}$ & PMC & Dmitri Utkin & $\begin{array}{l}\text { Syria, } \\
\text { Ukraine, } \\
\text { Libya, } \\
\text { Central African } \\
\text { Republic, } \\
\text { Sudan, } \\
\text { Burundi }\end{array}$ & $\begin{array}{l}\text { Training of elite forces, } \\
\text { direct participation in } \\
\text { battles }\end{array}$ & $\begin{array}{l}\text { Was } \\
\text { distinguished in } \\
\text { the Battle of } \\
\text { Debalceva and } \\
\text { in the liberation } \\
\text { of Palmyra }\end{array}$ \\
\hline $\begin{array}{l}\text { „RSB } \\
\text { Group“، }\end{array}$ & $\begin{array}{l}\text { PMSC/ } \\
\text { PMC }\end{array}$ & Oleg Krinitsyn & $\begin{array}{l}\text { Africa, } \\
\text { Middle East, } \\
\text { Central Asia, } \\
\text { Indian and } \\
\text { Atlantic Ocean, } \\
\text { Ukraine }\end{array}$ & $\begin{array}{l}\text { Protection of naval and VIP, } \\
\text { mine clearance and rebel } \\
\text { support }\end{array}$ & $\begin{array}{l}\text { Possibly } \\
\text { supported the } \\
\text { rebel side in the } \\
\text { Donbass war }\end{array}$ \\
\hline „PKSK Mar“ & $\begin{array}{l}\text { PMSC/ } \\
\text { PMC }\end{array}$ & $\begin{array}{l}\text { Aleksey } \\
\text { Marushchenko }\end{array}$ & $\begin{array}{l}\text { Libya, } \\
\text { Ukraine }\end{array}$ & $\begin{array}{l}\text { Provides armed protection } \\
\text { of objects and transport, } \\
\text { maintenance of public order } \\
\text { in extreme conditions, fire } \\
\text { suppression }\end{array}$ & $\begin{array}{l}\text { It was used } \\
\text { in Ukraine, } \\
\text { against local } \\
\text { forces }\end{array}$ \\
\hline $\begin{array}{l}\text { „E.N.O.T. } \\
\text { Corp“" }\end{array}$ & PMSC & $\begin{array}{l}\text { Roman } \\
\text { Telenkevich }\end{array}$ & $\begin{array}{l}\text { Ukraine, } \\
\text { Syria }\end{array}$ & $\begin{array}{l}\text { Rescues people, increases } \\
\text { the security of compatriots, } \\
\text { promotes ideological } \\
\text { education, carries out } \\
\text { preventive fights against } \\
\text { illegal migration, fights } \\
\text { against organized crime and } \\
\text { drug } \\
\text { trafficking }\end{array}$ & $\begin{array}{l}\text { Was } \\
\text { distinguished in } \\
\text { a cleaning } \\
\text { operation in } \\
\text { Anthracite, } \\
\text { Donbass }\end{array}$ \\
\hline
\end{tabular}

Source: compiled by author

Russian companies can only be considered "private" according to their official registration and supported discourse. According to Mark Galeotti, the Wagner group may appear at first glance as part of the private sector and pretend to be so, but if necessary, it can become a force that meets the needs of the state [17]. Such hired groups are not independent. Companies in Russia are supported by the military and controlled by the state [18]. This is the predominant hybrid business model. Pseudo-private companies achieve the goals set by the Kremlin not only in Russia, but also in conflicts in foreign countries [19]. The private sector of mercenaries in Russia is not considered to be identical to Western groups, so the word "private" in Russia can mean "fake" or "pseudo-private".

\section{Goals of Using Russian Federation Private Military Companies in Syria, Northeast and Central Africa, Ukraine and Venezuela}

Analyzing the cases, similar tendencies can be found why Russia sends the PMCs to certain regions, taking into account the interests of the state as explained by the principal-agent theory (see Fig 2).

- A comparison of Syrian and African countries shows that the most common aim in the regions is the misappropriation of natural resources. It would be financially useless to entrust the work to the regular forces to Russia, and it would be dangerous because of the threats there. Despite struggles over natural 
resources, Russia has about 30 percent of its territory of the world's resources, but after the collapse of the Soviet Union, a large part of oil and gas was exported [20], and, as the RF's foreign policy concept writes, the security of energy sources must be ensured [21];

- A comparison of the Syrian and Crimean regions shows that port control is a key objective. The port of Sevastopol in Crimea and Tartus in Syria are of strategic importance for access to the Black, Azov and Mediterranean seas and can therefore dominate and act as a deterrent [16];

- Finally, a comparison of all regions reveals the idea of Russia as a powerful state, which they seek to revive by dominating. Russia chooses such model because it cannot directly oppose the U.S. in order to regain its influence. Russia seeks power by competing against U.S. military power [22]. The remoteness of the regions (excluding Ukraine) creates inconveniences for Russia in financing or supplying its hired PMCs.

\section{Cases of Using Private Military Companies of the Russian Federation in Foreign and Security Policy. Cases of Syria, Northeast and Central Africa, Ukraine and Venezuela}

- Comparing analyzed cases of PMCs use in the regions, one can find similarities and differences in the activities of PMCs employed by Russia:

- Depending on the region other than Ukraine, the Kremlin conducts protection of oil, gas, gold and diamonds. They are reminiscent of PMSCs performing security functions and are therefore similar to Western companies. However, their type cannot be considered as PMSC, as in Ukraine, Syria and Africa, mercenaries are mainly involved in combat missions. Rather, it forms the image of the PMCs.

- A comparison of regions shows that fighting takes place in each country for different reasons:

- In Ukraine, fighting is taking place to suppress Ukraine's regular forces and destabilize Ukraine by controlling and supporting the DPR and LPR;

- In Syria, fighting is aimed at suppressing US opposition forces that are stationed in the region;

- In Africa, fighting ensures national security and exchanges access to gold and diamond mines.

- Comparing regions in different senses, it is possible to distinguish regions:

- $\quad$ in terms of diversity of resources, the most profitable regions are Syria and Africa;

- in terms of dominance, Syria and Ukraine, as they have different maritime access and the territory of Crimea;

- Venezuela remains the least successful region, as the geographical location of the US allows for greater influence over the country.

Although PMCs is more beneficial to Russia than the regular forces, over time, the problems explained by the principal-agent theory arise. Often in Ukraine, when checking the competence and reliability of mercenaries, there is an agency slack problem - Russia does not control undisciplined hired groups. It is most common in Syria and Africa when mercenaries take actions that do not match the principal - Russian wishes.

\section{Evaluation of Motives and Features}

Assessing the motives and features of the use of the Russian PMCs in different regions, it can be seen that, depending on the region, both the circumstances and the goals of the state differ, but the chosen strategy does not change. Although the outermost regions - Syria, African states and Venezuela - are expensive financially and logistically, in any case it is cheaper and safer for Russia to hire PMCs than to send regular forces. Taking into account the principal-agent theory, it can be stated that some of the factors mentioned in the theory are not appropriate for interpreting the case of Russia, therefore, taking into account the analyzed material, I would suggest supplementing them.

Circumstances of delegation that are not mentioned in theory, but should be (see Fig 3):

- selection of competent PMCs;

- international reaction to state choices;

- the inability of states to openly fight against other more powerful states. 

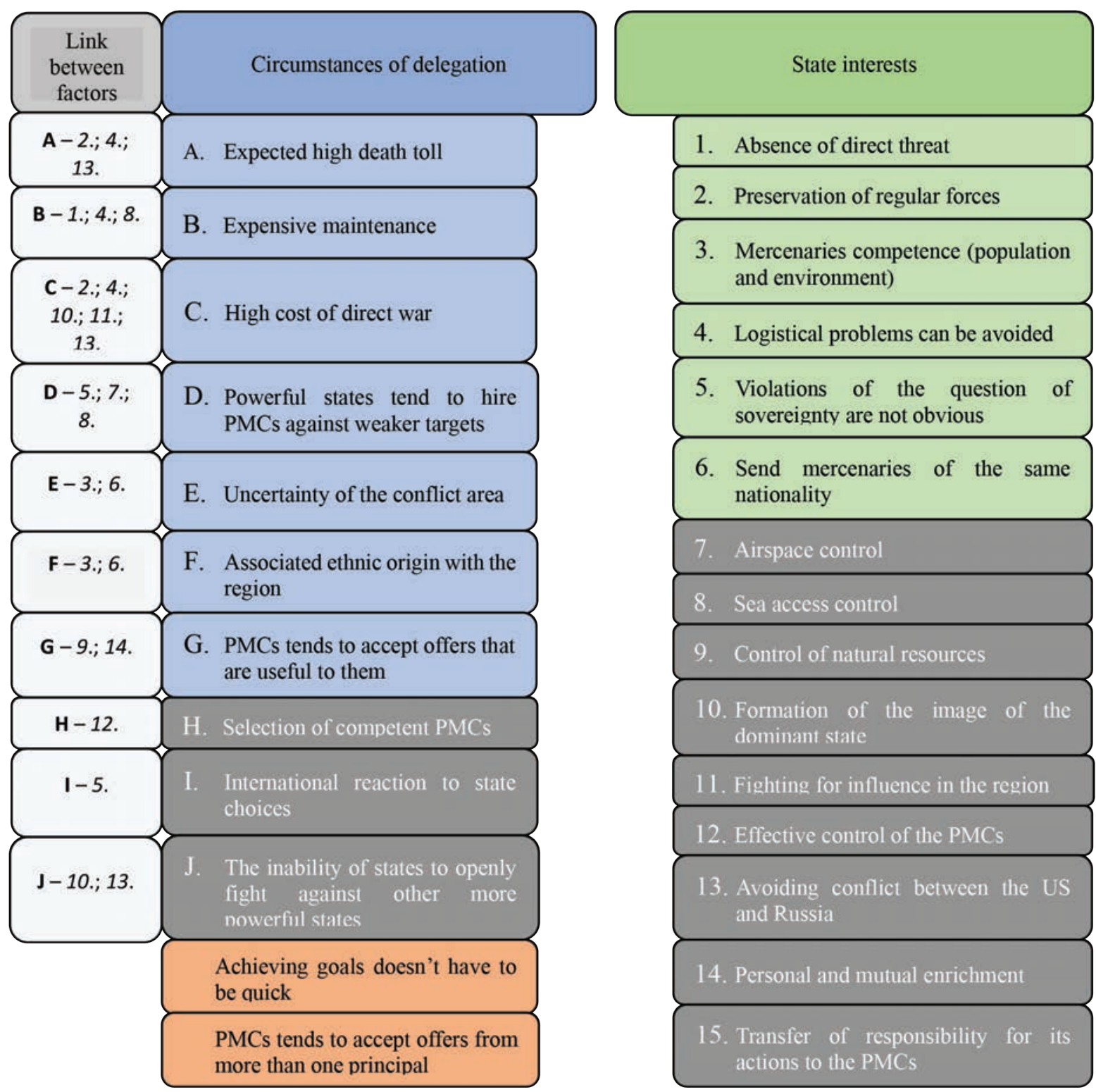

3. Mercenaries competence (population and environment)

4. Logistical problems can be avoided

5. Violations of the question of sovereignty are not obvious

6. Send mercenaries of the same nationality

7. Airspace control
8. Sea access control
9. Control of natural resources
10. Formation of the image of the
dominant state

Fig 3. Interface between the factors determing the delegation of works and the interests of the state (supplemented). Source: compiled by author

Russia's interests, which are not mentioned in theory, but should be (see Fig 3):

- $\quad$ airspace control;

- $\quad$ sea access control;

- control of natural resources;

- formation of the image of the dominant state;

- fighting for influence in the region;

- $\quad$ effective control of the PMCs;

- avoiding conflict between the US and Russia;

- $\quad$ personal and mutual enrichment;

- transfer of responsibility for its actions to the PMCs.

Based on the data analyzed in the study, it is noted that the main reasons why the work is not delegated to the regular forces, but to the PMCs are (see Fig 3):

- a high number of casualties during a direct war;

- financially expensive retention and participation in combat;

- The PMCs propensity to accept financially rewarding tasks. 
It is also noted that it is easier to operate in the Ukrainian region, because the state is not as difficult to access as others. However, Russia benefit more from the outermost regions. The diversity of countries allows Russia to dominate different parts of the world and its seas: the African continent, Eastern Europe, Western Asia (Middle East), Latin America, the Black Sea, the Mediterranean, and the Azov Sea.

\section{Conclusions}

Russia is one of the states that pursues its goals by hiring PMCs. As the nature and actors of war change, so does the level of analysis, examining the motives and features of states as it comes to hiring fighters. This type of study is relatively new and has not been examined in detail, as this theory has only been used in the U.S. case study. In line with its ambitions, Russia is choosing a strategy to hire PMCs, but such choice can raise two issues: mercenary agency slack problem and negative selection. In the case of Russia, a lack of discipline is the main issue. Analysis of the motives and features of PMCs employed in Russia's foreign and security policy suggests that the principal-agent theory is appropriate for the Russian case, but should be adjusted.

The Military and Naval doctrine of the Russian Federation, the concept of Foreign Policy and the National Security strategy until 2020 reveals Russia's aspirations and foreign and security policy goals in the studied regions. Official documents do not specify exactly how the goals are to be achieved, so Russia uses not only its regular forces but also PMCs to pursue its interests. Apart from documents, the activities of persons appointed by the Kremlin and PMCs entrusted them help to find out what are the state's interests. In the light of the analysis carried out, key interests can be identified by region. In general, all regions pursue strategic and operational interests, but not all hotspots are financially viable. Despite Ukraine, the rest of the countries where Russian-owned PMCs operate are in geographically inconvenient locations. As Ukraine is the closest, the Kremlin may be the most convenient region to seek strategic foothold in the Crimean peninsula, where Russia is consolidating its position by providing strategic deterrence to US missile defense systems deployed in Romania and controlling the port of Sevastopol. In such situation, the use of regular forces would not be appropriate from an international perspective, leading to the use of PMCs. Although Syria and African states are remote regions, with access to the port of Tartus in Syria and the port of Egypt, Russia is free to supply PMCs fighting in remote regions. In both Syria and Africa, the Kremlin seeks to control natural resources, maintain the image of a dominant state, and gain influence in the regions. Venezuela, meanwhile, is probably the most inconvenient region, as access to the area is only possible by air or water. Nevertheless, Russia supports the government of N. Maduro, thus seeking dominance in the state. By hiring PMCs instead of regular forces in different regions, Russia avoids not only responsibility for its actions, but also conflict with the United States, which is beneficial and effective in terms of foreign policy.

Analyzing the use of Russian PMCs in the regions, it was observed that the state is not able to directly conflict with more powerful actors of the system. It also shows a failure to guard against an international reaction. It is also clear that the Kremlin is not fully responsible for PMCs, as Russia selects individuals to oversee hired groups. The armaments and equipment used by PMCs are of Russian origin, so it is not difficult to distinguish who may support them with logistical supplies. While the mercenaries participated in combat missions, they also performed other noncombat work. Despite Russia's failed concealment of facts, the state was able to achieve almost all of its essential goals while avoiding direct responsibility for the actions of PMCs. However, there are cases when mercenaries are not controlled and perform work not assigned by Russia. In this situation, there is an agency slack problem. Although the Kremlin knows a lot about the companies, their expertise and readiness, the problem is with the discipline of the mercenaries. Analyzing the use of Russian PMCs in different regions, it was observed that the Kremlin fails to achieve its objectives effectively when hired groups are not purposefully controlled.

Assessing the general motives and features that led to the use of Russian PMCs, it was observed that the circumstances of delegation of activities explained in the principal-agent theory and the interests of the state do not define all possible and real factors. The factors revealed in the study related to the case of Russia are not mentioned in the theory. In order to ensure the development of theory in political science and to explain the behavior, motives and features of the state in hiring PMCs, the work presents a scheme based on the principal-agent theory. It reflects the circumstances of the delegation of activities and the interests of the state are complementary, adjusted and interrelated. Analyzing the cases of use of Russian PMCs, its interests and circumstances that led to the delegation of work to mercenaries, it can be stated that the factors are interrelated. Possibly the circumstances of the delegation of activities could be related to all the interests of the state, but the scheme provides essential links. In view of the assumption made in the investigation, which states that the reasons for using PMCs in the Russian Federation's foreign and security policy are close to conventional forces, avoiding responsibility for their actions, it can be confirmed, but it should be emphasized that it was observed that companies are more for combat than for security-related tasks. Given the specifics of the jobs and the diversity scheme of social deviations, PMSCs are more like regular forces. Although it is difficult to determine whether the motives for the use of both types of force are the same, it can be argued that they 
are similar because both choices help to achieve more or less the same interests. Although control of regular forces is simpler because of the disciplined military structure, PMCs, unlike conventional forces, help Russia avoid direct responsibility for delegated work.

Acknowledgements. The author would like to express his gratitude to Assoc. prof. Giedrius Česnakas from the Military Academy of Lithuania for his personal support in making this work happen.

\section{References}

1. M. v. Creveld, More on war, USA: Oxford University Press, 2017.

2. M. Kaldor, New and Old Wars: Organised Violence in a Global Era, 3rd ed., Cambridge: Polity, 2012.

3. S. Sukhankin, "War, Business and Ideology: How Russian Private Military Contractors Pursue Moscow's Interests," Jamestown Foundation, 2019.

4. Å. G. Østensen and T. Bukkvoll, Russian Use of Private Military and Security: the implications for European and Norwegian Security, Norway: Chr. Michelsens Institutt, 2018.

5. K. Marten, "Russia's use of semi-state security forces: the case of the Wagner Group," Post-Soviet Affairs, p. 1-24, 2019.

6. I. Salehyan, "The Delegation of War to Rebel Organizations," The Journal of Conflict Resolution, vol. 54, no. 3 , p. $493-515,2010$.

7. G. Hughes, My Enemy's Enemy: Proxy Warfare in International Politics, Brighton: Sussex Academic Press, 2014.

8. ICRC, "Protocol Additional to the Geneva Conventions of 12 August 1949, and relating to the Protection of Victims of International Armed Conflicts (Protocol I): International Committe of the Red Cross," 1977. [Online]. Available: https://ihl-databases.icrc.org/ihl/WebART/470-750057. [Accessed 1210 2019].

9. K. A. O'Brien, "Military-advisory groups and African security: Privatized peacekeeping?," International Peacekeeping, vol. 5, no. 3, pp. 78-105, 1998.

10. S. Percy, Mercenaries: The History of a Norm in International Relations, Oxford: Oxford University Press, 2007, p. 1.

11. United Nations, "Report on the question of the use of mercenaries as a means of violating human rights and impeding the exercise of the right of peoples to self-determination," United Nations Economic and Social Council, 1997.

12. J. L. Taulbee, "Reflections on the mercenary option," Small Wars \& Insurgencies, vol. 9, no. 2, pp. 146-163, 1998.

13. H. Tonkin, State Control over Private Military and Security Companies in Armed Conflict, New York: Cambridge University Press, 2011, p. 31.

14. J. Grieco, J. Ikenberry and M. Mastanduno, Introduction to International Relations, London: Red Globe Press, 2019, p. 79.

15. I. Salehyan, "The Delegation of War to Rebel Organizations," Journal of Conflict Resolution, vol. 54, no. 493, 2010.

16. Президент России, “Военная доктрина Российской Федерации,” 2014. [Online]. Available: http://static. kremlin.ru/media/events/files/41d527556bec8deb3530.pdf.

17. G. M., "Moscow's mercenaries reveal the privatisation of Russian geopolitics," open Democracy, 2017. [Online]. Available: https://www.opendemocracy.net/en/odr/chvk-wagner-and-privatisation-of-russian-geopolitics/. [Accessed 2312 2019].

18. E. N., "Russian Private Military Companies_-Redwater?," Eurasia Daily Monitor, vol. 14, no. 39, 2017.

19. M. O., "Putin's Secret Armies Waged War in Syria-Where Will They Fight Next?," Newsweek, 2018. [Online]. Available: https://www.newsweek.com/2018/01/26/putin-secret-army-waged-war-syria-782762.html. [Accessed 2312 2019].

20. K. K. M., "Russia's Natural Resources and their Economic Effects," 1997. [Online]. Available: https://personal. ems.psu.edu/ williams/russia.htm. [Accessed 0312 2019].

21. МРФ, “Концепция внешней политики Российской Федерации,” 2016. [Online]. Available: https://www.mid. ru/foreign_policy/official_documents/-/asset_publisher/CptICkB6BZ29/content/id/2542248.

22. Президент России, “Стратегия национальной безопасности Российской Федерации,” 2015. [Online]. Available: http://kremlin.ru/acts/bank/40391/page/1.

23. M. Kaldor, New and Old Wars: Organised Violence in a Global Era, Cambridge: Polity, 2012, pp. 1-15.

24. S. S. Gartner, "American Political Science Associationis collaborating with JSTOR to digitize, The Multiple Effects of Casualties on Public Support for War: An Experimental Approach," American Political Science Review, vol. 102, no. 1, pp. 95-106, 2008. 
25. L. H. Wimberley, Pyrrhic Peace: Governance Costs and the Utility of War, San Diego: University of California, 2007.

26. СБРФ, “Морская доктрина Российской Федерации,” 2015. [Online]. Available: http://www.scrf.gov.ru/ security/military/document34/.

27. Hawkins, D. G., Lake, D. A., Nielson, D. L., \& Tierney, M. J., Delegation and Agency in International Organizations, New York: Cambridge University Press, 2006.

28. Herbst, J. E., \& Marczak, J., Russia’s Intervention in Venezuela: What's at Stake?, Washington: Atlantic Council, 2019.

29. Kofman, M., Migacheva, K., Nichiporuk, B., Radin, A., Tkacheva, O., \& Oberholtzer, J., Lessons from Russia's Operations in Crimea and Eastern Ukraine, Santa Monica: RAND Corporation, 2017.

30. G. Kuczyński, U.S. Foothold - Russian stance towards crisis in Venezuela, Poland: Warsaw Institute, 2019.

31. S. Sukhankin, Unleashing the PMCs and Irregulars in Ukraine: Crimea and Donbas, Washington: Jamestown Foundation, 2019.

32. K. Marten, "Russia's use of semi-state security forces: the case of the Wagner Group," Post-Soviet Affairs, pp. 1-24, 2019.

33. A. McGregor, "Falling off the Fence: Russian Mercenaries Join the Battle for Tripoli," Eurasia Daily Monitor, vol. 16, no. 138, 2019. 